\title{
ATATÜRK'ÜN DOĞUMU VE ÇOCUKLUK YILLARI (1881-1893)
}

(Atatürk's Birth And Childhood Years) (1881-1893)

Alaattin $\mathbf{U C A}^{\bullet}$

\section{ÖZET}

Türkiye Cumhuriyeti'nin kurucusu ve ilk Cumhurbaşkanı Atatürk, 1881 yılında Selanik'te Kasımiye mahallesi, Islahhane caddesinde şimdi müze olan evde doğdu. Babası Ali Rıza Efendi ve annesi Zübeyde Hanım'dır.

Atatürk çok kısa bir süre mahalle mektebine devam ettikten sonra, modern usullere göre eğitim veren Şemsi Efendi Okulu'nda okudu.

Babasının ölümünden sonra $\mathrm{O}$, annesiyle birlikte dayısının çalıştığı çiftliğe gitti. Sonra Selanik'teki teyzesinin yanına döndü. Bir süre sivil ortaokula devam ettikten sonra, 1893'de askeri okula girdi.

$\mathrm{Bu}$ çalışmada Atatürk'ün doğumu, çocukluk yılları ve askeri okula girişine kadarki dönem üzerinde durulmaktadır.

Anahtar Kelimeler: Atatürk, Atatürk'ün doğumu, Atatürk'ün çocukluk yılları.

\section{ABSTRACT}

Atatürk, the founder and the first President of the Turkish Republic, was born in the Kasımiye Quarter of Salonica in the house on Islahhane Street which is now a museum in 1881. His father is Ali Riza Efendi and his mother is Zübeyde Hanım.

Atatürk, after having attended the neighborhood school for a very short while, attended and graduated from the modern oriented school of Şemsi Efendi.

After the death of his father he went with his mother to the farm on which his uncle was working. Later, returned to live with his aunt at Salonica. He attended the civil state high school for a short while. After that he entered the Military Secondary School at Salonica in 1893.

This study covers Atatürk's birth, childhood years and entering the civil state high school.

Keywords: Atatürk, Atatürk's birth, Atatürk's childhood years.

• Atatürk Üniversitesi Türkiyat Araştırmaları Enstitüsü

TAED 31, 2006, 1-13 
“Bana insan üstü bir doğuş yakıştırmaya kalkışmayınız; doğuşumdaki tek olağanüstülük, Türk olarak dünyaya gelmemdir. ${ }^{\text {"” }}$

K.ATATÜRK

Cok az insana nasip olur doğumunun 125. y1lında anılmak, kalplerde yaşamak, gönüllerde taht kurmak, halkı tarafından sevilmek, yani unutulmamak, hatta hiç unutulmayacak olmak, eserler bırakmak, eserleriyle anılmak. Bırakılan eser Devlet olunca, birakılan eser Cumhuriyet olunca eserin sahibi daha bir farklı olur. Dolayısıyla, son büyük Türk devleti olan Türkiye Cumhuriyeti'ni kuran Atatürk, devlet kurucusu olarak, Türk Milleti'nin kalbinde, ilk devletimiz Büyük Hun İmparatorluğu'nu kuran Teoman, Göktürk İmparatorluğu'nu kuran Bumin Han, Avar İmparatorluğu'nu kuran Bayar Kağan, Uygur Devleti'ni kuran Boyla Kağan, Karahanlılar Devleti'ni kuran Bilge Kül Kadır Han, Gazneliler Devleti'ni kuran Alp Tekin, Büyük Selçuklu İmparatorluğu'nu kuran Selçuk Bey, Anadolu Selçuklu Devleti'ni kuran Süleyman Şah, Osmanlı İmparatorluğu'nu kuran Osman Bey ve fazla uzatmamak için daha adını saymadığımız pek çok Türk Devletlerinin kurucularıyla aynı değere hatta daha fazlasına sahiptir. Çünkü $O$, yeni bir devlet kurarken imkânsızı gerçekleştirdi. Yokluklar, kıtlıklar, işgaller altında yepyeni bir devleti, Türkiye Cumhuriyeti'ni kurmayı başardı.

Bu büyük insan, bu büyük eserin sahibi köşklerde, saraylarda doğmadi. Hanedan üyesi ya da bir tahtın varisi değildi. Sade bir evde, mütevazi bir ailede dünyaya geldi. ${ }^{2}$

Babası Ali Rıza Efendi, Anadolu'dan ${ }^{3}$ Rumeli'ye geçmiş olan Kocacık ${ }^{4}$ Yörüklerinden Hafız Ahmet Efendi isminde bir zatın oğludur. ${ }^{5}$ Yani Evlâd-1 Fatihandır. $^{6}{ }^{7}$

\footnotetext{
${ }^{1}$ Falih R. Atay, Babanız Atatürk, Bayrak, Atatürkçülük Nedir, Atatürk Ne İdi, İstanbul, 1980, s.8.

${ }^{2}$ Celâl Erikan, Komutan Atatürk, Ankara, 1972, C.I, s.1.

${ }^{3}$ A. Muhtar Kumral, Atatürk Diktatör müdür ?, İstanbul, 1949, s.9.

${ }^{4}$ Kocacık, Manastır ilinin Debrei Bâlâ (Yukarı Debre) sancağına bağlı bir nahiyedir ve halkı Anadolu'dan gitme ve tamamıyla Türk, Müslüman Oğuzların Türkmen boylarındandır. Bk. Numan Kartal, Atatürk ve Kocacık Türkleri, Ankara, 2002, s.41.

${ }^{5}$ Ş. Süreyya Aydemir, Tek Adam Mustafa Kemal (1881-1919), Üçüncü Baskı, İstanbul, 1966, s.47.

${ }^{6}$ Ali Güler, Atatürk Soyu Ailesi ve Öğrenim Hayatı, Ankara, 1999, s.26.

${ }^{7}$ Anadolu'dan Rumeli'ye geçen ve Rumeli'nin Manastır, Pirlepe, Florina, Radovişte, Usturumca, İştip, Cuma, Dovran, Avratpazarı, Tikveş, Demirhisar, Serez, Zihne, Vodina (Zübeyde Hanım'ın babası, buradan Selanik'e gelmiştir.), Yenice, Langaza (Atatürk’ün dayısı burada
} 
Ali Rıza Efendi'nin annesinin adı ise Ayşe Hanımdır. ${ }^{8}$ Ali Rıza Efendi’nin Rukiye Hanım isminde bir kız kardeşi ve Salih Bey isminde bir de erkek kardeşi vard1. ${ }^{9}$ Ali Rıza Efendi, Katarin kazasında gümrük muhafaza memurluğunda, evkaf kâtipliğinde ve rüsumat memurluğunda bulundu. ${ }^{10}$

Ali Rıza Efendi'nin, Selanik’te kurulan ve gönüllülerden oluşan bir askeri taburda gönüllü birinci mülazım (üsteğmen) olarak yer aldığ 1 ve hatta 1876 yılında Mithat Paşa'nın ilk Meşrutiyeti ilanı sırasında bu taburla birlikte İstanbul'a geldiği de ifade edilmektedir. ${ }^{11}$ Ancak, Atatürk bu ifadeyi tasvip etmemiştir. $^{12}$

Atatürk'ün Annesi Zübeyde Hanım ise Vodina'dan Selanik'e gelmiş olan Hacı Sofu ailesinden Feyzullah Ağa'nın kızıdır. ${ }^{13}$ Zübeyde Hanım'ın annesinin ismi Ayşe Hanım'dır. Atatürk'ün bir teyzesi ve Hasan ve Hüseyin Ağa isminde iki dayısı ile birkaç da yeğeni vardı. ${ }^{14}$

Ali Rıza Efendi ve Zübeyde Hanım Selanik’te evlendiler. Bu evliliğin tarihi kesin olarak bilinmemektedir. Bazı kaynaklarda 1870-1871 tarihleri arasında evlendikleri ifade edilirken ${ }^{15}$, bazı kaynaklarda da 1876 'da evlendikleri söylenmektedir. ${ }^{16}$ Ali Rıza Efendi, evlendiği zaman, Gümrük idaresinde memur olarak çalışıyordu. Çalıştığı yer Selanik'ten epeyce uzakta Türk-Yunan sınırındaki Çayağzı yahut Papaz Köprüsü denilen bölgeydi. Daha önceleri Evkaf Dairesindeki kâtiplikten ve Asâkir-i Milliye taburundaki gönüllülükten önce Batı Trakya'da ve Makedonya'da da memurluk görevinde bulunmuştu. İlk evlendiklerinde Zübeyde Hanım, Ali Rıza Efendi'nin ailesinin yaşadığı Selanik'te Yenikapı mahallesindeki evlerine yerleşti. Bir süre sonra Papaz Köprüsüne geldiler. Ancak burada şartlar çok kötüydü. Zorda olsa bu şartlara

yaşıyordu.), Drama şehir ve kasabalarında ve bunların civarında oturan Rumeli fatihlerinin evlatları ile bu kıta fetholundukça Anadolu'nun muhtelif yerlerinden getirilip iskân edilmiş olanlara Evlâd-ı Fatihan denilir.(bk.:Midhat Sertoğlu, Osmanlı Tarih Lûgatı, İst., 1986, s.105.)

${ }^{8}$ Burhan Göksel, Atatürk'ün Soykütüğü Üzerine Bir Çalışma, Ankara, 1994, s.9.

${ }^{9}$ Aydemir, Tek Adam Mustafa Kemal (1881-1919), s.47.

${ }^{10}$ Salih Omurtak, vd., Atatürk, İstanbul, 1970, s.1.

11 İslâm Ansiklopedisi, Eskişehir, 1997, C.I, s.719.

${ }^{12}$ Falih Rıfkı Atay, Çankaya, İstanbul, 1969, s.17.

${ }^{13}$ Atatürk Diyor ki Atatürk'ün Direktifleri Düşünceleri ve Kısaca Hayatı, İstanbul, 1966, Altıncı Baskı, Varlık Yayınevi, s.9.

${ }^{14}$ Aydemir, Tek Adam Mustafa Kemal (1881-1919), s.47.

15 Ali Güler, "Mustafa Kemal'i Atatürk Yapan Süreçte Aile Çevresi İle İlk Ve Orta Öğrenim Yaşantısının Rolü”, Atatürk ve Manastır Sempozyumu 12-13 Ekim 1998, Ank., 1999, s.83.

${ }^{16}$ Feridun Ergin, Kemal Atatürk, Yaşar Eğitim ve Kültür Vakfı Yayınları, 1978, s.22. 
katlandılar. Hatta burada iki çocuklarını kaybettiler. ${ }^{17}$ Mevcut duruma daha fazla dayanamayan Ali Rıza Efendi istifa ederek kereste ticareti ile uğraşmaya başladı. $\mathrm{Bu}$ işle meşgul olurken o yöredeki Yunan eşkıyasının saldırıları yüzünden büyük zarar gördü. Bu yüzden tekrar Selanik'e nakletmek zorunda kaldı ve burada Atatürk'ün doğduğu o meşhur pembe boyalı ahşap evi yaptırdı. ${ }^{18}$

Atatürk, 1881 yılında ${ }^{19}$ Selanik'de Ahmet Subaşı Mahallesi'nde (Kasımiye Mahallesi ) Islahhane Caddesi'nde bu gün müze olan pembe boyalı bu ahşap evde doğdu. ${ }^{20}$

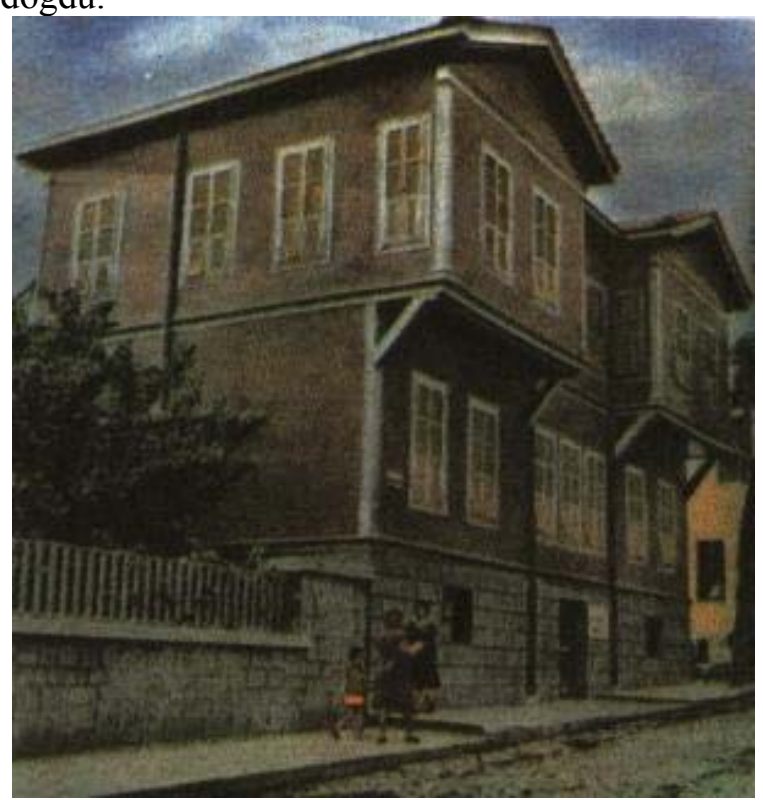

Resim 1: Atatürk'ün doğduğu ev

${ }^{17}$ Aydemir, Tek Adam Mustafa Kemal (1881-1919), s.40-42.

${ }^{18}$ Kılıç Ali, Atatürk'ün Hususiyetleri, Yeni Gün Haber Ajansı Basın ve Yayıncılık A.Ş., 1998, s.13-14.

${ }^{19}$ Atatürk'ün doğum tarihi bazı eserlerde 1880 olarak ifade edilmektedir. Hatta bu tarihten birkaç yıl daha evvel olduğunu söyleyenler de vardır. (Hüseyin Şekercioğlu; "Atatürk'ün Soy ve Sülalesi Hakkında Anadolu'da Yaptı̆̆ım Araştırmalar”, Türk Kültürüi, Kasım 1974, S.145, s.6; Sadi Borak, "Atatürk Hangi Yılda Doğdu”; Asım Arar, “Ata'nın Doğumu Hakkında”, Her Yönüyle Atatürk, (Editör: Avni Altıner), İstanbul, 1974, 2.Bask1, s.26, 27. Hatta bir kitabın içinde dahi farklı tarihlere rastlamak mümkündür. (bk. F. Perrone Di San Martino; Ön Asya Diktatörü Mustafa Kemal ve Zaferleri, Yayına Hazırlayan: Enver Sedat Akaltın, İstanbul, 1998, s.XI, 23.)

${ }^{20}$ Halil İbrahim Göktürk, Atatürk ve Çağlarını Aşanlar, Sena Matbaası, 1981, s.X.

TAED 31, 2006, 1-13 
Atatürk'ün doğduğu evin bulunduğu mahalle bazı kaynaklarda Koca Kasım Mahallesi olarak da geçmektedir. ${ }^{21} \mathrm{Bu}$ ev bu gün Apostolu Pavlu veya Agiou Dimitriou Sokağındaki 71 No.lu binadır. Selanik’teki Konsolosluğumuzun bahçe sınırları içindedir. Selanik Belediyesi 12 Şubat 1937'de aldığı bir kararla bu binayı sahibinden satın alarak Atatürk'e armağan etti. ${ }^{22}$

O’nun doğumu şüphesiz ki Türk ve dünya tarihinin önemli olaylarından biri oldu. Çünkü O, askeri ve siyasi alandaki faaliyetleriyle hem dünya tarihini etkiledi hem de Türk Milletinin istikbâlini belirledi.

O gün ${ }^{23}$ bu mütevazi evde bir bayram havası yaşandı. Babası Ali Rıza Efendi, Türk toplumundaki ad verme geleneklerinden birine uyarak, O'na daha önce ölen kendi kardeşi Mustafa'nın adını koydu. ${ }^{24} \mathrm{Bu}$ isim, aynı zamanda Hz.Muhammed'in ismiydi ve "Seçilmiş Kişi”" anlamına geliyordu. ${ }^{25}$ Baba'nın ve Anne'nin mutluluğuna diyecek yoktu, çünkü önceleri yaşamamış olan üç çocuktan sonra (Fatma, Ömer ve $\mathrm{Ahmet}^{26}$ ) yeni bir erkek evlada kavuşmuşlardı. ${ }^{27}$ Atatürk'ün Makbule Hanım ve Naciye Hanım isimlerinde iki de kız kardeşi vardı. Ancak Naciye Hanım da küçük yaşta vefat etti.

Atatürk, kardeşi Makbule Hanım, annesi Zübeyde Hanım ve babası Ali Rıza Efendi ile birlikte Selanik'te mutlu bir çocukluk dönemi geçirdi.

${ }^{21}$ Mehmet Özel, Atatürk, T.C. Kültür Bakanlığı Güzel Sanatlar Genel Müdürlüğü, (albüm), s.4.

${ }^{22}$ Cemal Kutay, Atatürk Olmasaydı?, İstanbul, 1993, s.2; Mehmet Rado, "Bu Evde Bir Tarih Doğdu”, Her Yönüyle Atatürk, (Editör: Avni Altıner), İstanbul, 1974, s.30.

${ }^{23}$ Doğum günü kesin olarak bilinmemekle beraber, Atatürk, doğum gününü soranlara, "neden 19 Mayıs olmasın" cevabını verirdi. (Bk.Hamza Eroğlu, Atatürk'ün Hayatı, Ankara, 1986, s.9.); Ayrıca, 19 Mayıs 1932'de Reşit Saffet Atabinen'in kendisine "Doğum gününüzü kutlarım."şeklinde bir telgraf çekmesi de Atatürk'ün hoşuna gitmişti. (Hikmet Bayur, Atatürk Hayatı ve Eseri, Ankara, 1990, s.7.); Bazı yazarlara göre, aşırı kutlamalar yapılmasın diye Atatürk, doğum gününün bilinmesini istemiyordu. (Niyazi Ahmet Banoğlu, Yayınlanmamış Belgelerle Atatürk Siyasi ve Özel Hayatı İlkeleri, İstanbul, 1981, s.11.); Atatürk'ün doğum günü olarak, çeşitli kaynaklarda 13 Mart 1881, 23 Aralık 1880, 4 Ocak 1881, 19 Mayıs 1881 tarihleri telaffuz edilmektedir. (Muhtar Kumral, "Atatürk'ün Doğum Günü Nasıl Tespit Edildi?”; Mustafa Baydar, “Atatürk Ne Zaman Doğdu”, Her Yönüyle Atatürk, (Editör: Avni Altıner), İstanbul, 1974, 2.Baskı. s.27, 24.

24 Alaattin Uca, “Türk Toplumunda Ad Verme Geleneği”, Türkiyat Araştırmaları Enstitüsü Dergisi, Erzurum, 2004, S. 23, s. 146.

25 Andrew Mango, Atatürk, ( çev: Füsun Doruker ), İstanbul, 2000, s.29; Ferit Devellioğlu, Osmanlıca-Türkçe Ansiklopedik Lûgat, (Yayına hazırlayan: Aydın Sami Güneyçal), Ankara, 1993, s.688.

${ }^{26}$ Aydemir, Tek Adam Mustafa Kemal (1881-1919), s.40.

${ }^{27}$ Göktürk; Atatürk ve Çağlarını Aşanlar, s.X.

TAED 31, 2006, 1-13 
Sonunda tahsil çağına geldi. Her çocuk gibi O'nun da okuması gerekiyordu. Annesi, eski geleneklere uyularak, ilahilerle mahalle mektebine başlamasını ve hafız olarak yetiştirilmesini istiyordu. Babası Ali Rıza Efendi ise, o zaman Selanik'te yeni bir eğitim sistemi uygulayan Şemsi Efendi Mektebi'ne devamını arzu ediyordu. ${ }^{28}$ Atatürk önce geleneksel merasimle Hafiz Mehmet Efendi'nin mahalle mektebine kaydedildi. ${ }^{29} \mathrm{Bu}$ suretle annesinin gönlü yapıldı ve arzusu yerine getirildi. Bir süre sonra Atatürk, buradan alınarak çağdaş eğitim yapan Şemsi Efendi Mektebi'ne kaydedildi. Böylece babasının da arzusu

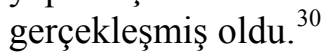

Aslında Atatürk'ün çocukluk yıllarında karşılaştığı bu durum, eski ile yeninin tartışmasıydı ve ileriki yaşantısını dahi etkileyecek bir olaydı. ${ }^{31}$ Annesi eskiyi, babası ise yeniyi ya da geleceği temsil ediyordu ve bu olay ülkenin gelecekteki değişiminin habercisiydi. ${ }^{32}$

Atatürk, bu konuyu, Ankara'da kendisiyle bir görüşme yapan Vakit Gazetesi yazarı Ahmet Emin Yalman'a şöyle anlattı: “Çocukluğuma dair ilk hatırladığım şey, okula gitmek meselesine aittir. Bundan dolayı anamla babam arasında şiddetli bir çatış̧ma vardı. Annem, ilahilerle okula başlamamı ve mahalle okuluna gitmemi istiyordu. Gümrükte memur olan babam, o zaman yeni açılan, Şemsi Efendi'nin okuluna gitmemi ve yeni yöntemlere göre okumamı yĕ tutuyordu. Nihayet babam işi ustaca çözdü. İlk önce bilinen törenle mahalle okuluna başladım. Böylece annemin gönlü yapılmış oldu. Birkaç gün sonra da mahalle okulundan çıktım; Şemsi Efendi'nin okuluna yazıldım. "33

Bu olay, Atatürk'ün kişiliğinde etkili olmuş, ilginç bir olaydır. Atatürk bu vesileyle, kadının Türk toplumundaki yeri hakkında ilk dersi de babasından almış oldu. ${ }^{34}$

Atatürk'ün Şemsi Efendi Okulunda öğrenime başlaması bir şanstı. Çünkü o okulda günün şartlarına göre, çok yetenekli öğretmenler vardı. Onların da

\footnotetext{
${ }^{28}$ Halûk Şehsuvaroğlu, Tarihçi Gözüyle Atatürk, Ankara, 1963, s.4.

${ }^{29}$ Utkan Kocatürk, Atatürk, Ankara, 1987, s.3.

30 Lord Kinross, Atatürk Bir Milletin Yeniden Doğuşu, (çev: Ayhan Tezel), İstanbul, 1978, s.2728.

${ }^{31}$ Ayşe Afetinan, Mustafa Kemal Atatürk'ün Karlsbad Hatıraları,Yeni Gün Haber Ajansı Basın ve Yayınc1lık A.Ş., Nisan 1999, s.35.

32 Jorge Blanco Villalta, Atatürk, Ankara, 1979, s.6.

${ }^{33}$ Uluğ İ̆gdemir, Atatürk'ün Yaşamı 1881-1918, I. Cilt, Ankara, 1988, s.3.

${ }^{34}$ Eroğlu, Atatürk'ün Hayatı, s.11.
} 
katkısıla Atatürk, okulu ve derslerini sevdi ve ne olursa olsun okumaya burada karar verdi. Buradaki öğretmenler O'nun ufkunu açtı. ${ }^{35}$

Atatürk'ün çocukluğundaki mutluluğu ve ilk tahsil hayatı fazla uzun sürmedi. Çünkü O yedi-sekiz yaşında iken babası Ali Rıza Efendi vefat etti. ${ }^{36} \mathrm{O}$ ' nun ölümü, Zübeyde Hanım’ı tabiî ki olumsuz yönde etkiledi ve çok sarstı.

Aslında bu olay en çok Atatürk'ün hayatını değiştirdi ve O'nun kişiliği üzerinde önemli rol oynadı. Çocuk yaşta yetim kalması O'nda "güçlenme içgüdüsü" ve kendi kendine karar verme yeteneğini ve çocuk sevgisini geliştirdi. $^{37}$

Ekonomik açıdan da sıkıntıya düşen Zübeyde Hanım, o sırada yedi yaşında olan Atatürk'ün tahsilini durdurmaya ve kızı Makbule Hanımı da yanına alarak, kardeşi Hüseyin Efendi'nin yanına gitmeye mecbur kaldı. ${ }^{38}$ Atatürk'ün dayısı Hüseyin Efendi, Langaza civarında Rapla köyünde yaşıyordu. Atatürk buraya geldiğinde, köy hayatını hiç yadırgamadı.

Bu durumu da şöyle anlatırdı: "Babam öldükten sonra annem ile birlikte dayımın köyüne gittik ve oraya yerleștik. Dayım tam manasıyla bir köy hayatı geçiriyordu. Çocukluk bu ya, ben de o hayata derhal karıştım ve çok da hoşuma gitti. Dayım çiftlikte kâhyalık ediyordu. Bana da vazife verdi. Benim başlıca işim tarla bekçiliği idi. Kardeşim Makbule ile beraber bakla tarlasının kulübesinde oturur, tarladan kargaları kovmakla meşgul olurduk. Hatta bir gün, hiç unutmam, Makbule ile yoğurt yiyorduk. Aramızda kavga çıktı. Makbule'nin başını tuttum, yoğurt çanağının içine soktum. Yüzü gözü yoğurt olmuştu!" "39

Atatürk çocukluğuna ait bu hatırayı anlatırken hep gülerdi ve bu durumu Makbule Hanıma da zaman zaman tekrar ettirirdi.

Atatürk'ün çocukluğunda yaşadığ 1 bu köy hayatı onda toprak ve vatan sevgisini ve ilerde yurdu saldırılara karşı koruyacak Büyük Adam'ın ilk sahip olma, koruma duygularını, ${ }^{40}$ bitki ve hayvan sevgisini geliştirdi ve cesaretini artırdı. ${ }^{41} \mathrm{O}$ gün tarlayı bekleyen, kargaları kovan Atatürk, gün geldi, yurdun

\footnotetext{
${ }^{35}$ Osman Bircan, Belge ve Fotoğraflarla Atatürk'ün Hayat1, İstanbul, 1993, s.8.

${ }^{36}$ Enver Behnan Şapolyo, Kemal Atatürk ve Milli Mücadele Tarihi, Ankara, 1944, s.22.

${ }^{37}$ Güler, "Mustafa Kemal'i Atatürk Yapan Süreçte Aile Çevresi...", s.87.

${ }^{38}$ Lord Kinross, Atatürk The Rebirth Of A Nation, , London, , 1966, s.7.

${ }^{39}$ Kılıç Ali, Atatürk'ün Hususiyetleri, s.15-16.

${ }^{40}$ Atatürk 1880-1938, Ankara, 1939, Ulus Basımevi, s.14.

${ }^{41}$ Cemil Sönmez, Atatürk ve Çocuklar, UNICEF Türkiye Temsilciliği, 1991, s.32, 35.
} 
başını bekledi; Türk Milletini tarih sahnesinden silmeye çalışan düşmanları kovup, Cumhuriyeti kurmayı başardı. ${ }^{42}$

Kişisel özellikleri o günlerde şekillenmeye başlayan Atatürk, Makbule Hanım'ın ifade ettiği gibi, çiftlikte hiç boş durmuyor, kendi oyuncağını kendi yapıyor ve devamlı meşgul olacak bir şeyler buluyordu. Ancak birkaç deneme yapılmasına rağmen, eğitimi konusunda olumlu gelişme sağlanamıyordu. Bir ara civardaki Rum okullarından birine verilmek istendiyse de sonradan bundan vazgeçildi. Çiftliğin yazıcısının verdiği derslerden de pek hoşlanmadı. Zira kendisine ders verecek kişileri yetersiz buluyor, beğenmiyordu. ${ }^{43}$ Bazen de çocukça yaramazlıklar yapıyor ve çoğu zaman yalnız kalmayı tercih ediyordu. ${ }^{44}$

Atatürk'ün köy hayatı bir süre devam ettikten sonra, Zübeyde Hanım, oğlunun okulsuz kalmasından müteessir olarak endişelenmeye başladı. ${ }^{45}$ O'nun tahsiline çok önem veriyordu ama asker olmasını istemiyordu. $\mathrm{Bu}$ yüzden Atatürk'ü, Selanik'e götürerek Hacı Şükrü Efendi Mülkiye Rüştiyesi'ne kaydedilmesini sağladı. Ancak bu okuldaki bir dayak olayı ve okulda giyilen kıyafetler Atatürk'ü rahatsız etti ve büyük annesi Ayşe Hanım ${ }^{46}$, O'nu bu okuldan çıkard1.

Atatürk, çocukluk hayatının bu bölümünü ise şöyle ifade ederdi: “...Annem okulsuz kaldığım için kaygılanmaya başladı. Nihayet Selanik'te bulunan teyzemin yanına gitmeme ve okula devam etmeme karar verildi. Selanik'te Mülkiye Rüştiyesi'ne yazıldım. Okulda Kaymak Hafız adında bir öğretmen vardı. Bir gün sınıfımızda ders verirken ben bir çocukla kavga ettim. Çok gürü̈ltü oldu. Ö̆gretmen beni yakalad, çok dövdü. Bütün vücudum kan içinde kaldı. Büyük annem zaten okulda okumamı istemiyordu. Beni derhal okuldan çıkardı. ${ }^{47}$

Atatürk'ün çocukluk yıllarında mahalle mektebinde ve de Mülkiye Rüştiyesi'nde yaşadığı olumsuzluklar ve Şemsi Efendi'nin modern usuldeki

\footnotetext{
${ }^{42}$ Eflâtun Cem Güney, Atatürk Hayat1 ve Eserleri, İstanbul, 1963, s.4.

${ }^{43}$ Hadi Besleyici, Atamız Atatürk, Dilek Yayınevi, 1980, s.14; Ali Fuat Cebesoy, Sınıf Arkadaşım Atatürk, İstanbul, 1967, s.5.

${ }^{44}$ Thomas A Vaidis, Kemal Atatürk Yeni Türkiye'nin Kurucusu -Yunanlı gözüyle Atatürk-, (çev; Ahmet Angın), İstanbul, 1967, s.57.

${ }^{45}$ Bekir Tünay, Gazi’nin Doğuş Destanı I, Ankara, 1981, s.24.

${ }^{46}$ Atatürk'ün babaannesi ve anneannesi aynı adı taşımaktadır. Bk. Göksel, Atatürk'ün Soykütüğü Üzerine Bir Çalışma, s.9,10.

${ }^{47}$ İğdemir, Atatürk'ün Yaşamı 1881-1918, s.4.
}

TAED 31, 2006, 1-13 
öğretim metotları ülkemizin eğitim sistemini buna göre değiştirmesinde etkili oldu.

Atatürk, asker olmak istiyordu ama annesi bunu kabul etmiyordu. ${ }^{48} \mathrm{Bu}$ nedenle Atatürk annesine söylemeden, komşuları Binbaşı Kadri Bey'in de teşvikiyle sınava girdi ve başarılı olarak 1893'de Selanik Askeri Rüştiye'sine kayit oldu. ${ }^{49}$ Bazı kaynaklarda bu tarih 1894 olarak da ifade edilmektedir. ${ }^{50},{ }^{51}$ Böylece hayatında yeni bir dönem başladı.

Atatürk, bu dönemin başlamasını ise sonradan şöyle anlatırdı: "Karşımızda Binbaşı Kadri Bey adında bir kişi oturuyordu. Ŏğlu Ahmet Bey Askeri Rüsstiye'ye gidiyordu ve okul elbisesi giyiyordu. Onu gördükçe ben de böyle elbise giymeye hevesleniyordum. Sonra sokaklarda subaylar görüyordum. Bu dereceye ulaşmak için izlenmesi gereken yolun, Askeri Rüştiye'ye girmek olduğunu anlyyordum. O strada annem de Selanik'e gelmişti. Askeri Rüştiye'ye girmek istediğimi söyledim. Annem askerlikten korkardı. Asker olmama şiddetle karşı çıktı. Giriş sınavı zamanı ona sezdirmeden kendi kendime Askeri Rüştiye’ye giderek sınav verdim. Böylece anneme karşı bir oldu bitti yapmış oldum. ",52

Annesi Zübeyde Hanım'ın o günlerde rüyasında, oğlunun elinde altın tepsi ile bir minareye çıktığını görmesi, O'nun istikbali için bir hayır alameti, parlak bir istikbalin müjdecisi olarak tabir edildi. Gerçekten de öyle oldu ve Milletin istikbali de onunla parladi.

Atatürk'ün çocukluğu hakkında şüphesiz ki en önemli kaynak olan Annesi Zübeyde Hanım, O'nun çocukluğunu şöyle anlatırdı: “Mustafam küçücük çocukken bile gayet temiz giyinirdi. Adeta büyük bir adam gibi tavirlar altr, herkesle büyükmüş gibi konuşurdu. Mahalle çocukları sokakta oynarlarken onların taş, sapan gibi sokak oyunlarına, ayak atlamalarına, koşmacalarına iltifat etmez, onlara bir nevi istihfafla (önem vermeme) bakard. O'nun kendisine mahsus bir benliği vardı. Ellerini pantolonunun cebine koyarak ve başını yukarıya dikerek konuşması daima hepimizin nazarı dikkatini celb

\footnotetext{
${ }^{48}$ Benoist Mechin, Mustafa Kemal Bir İmparatorluğun Ölümü, (Çeviren: Zeki Çelikkol ), Ankara, 1997, s.67, 68.

49 Turhan Feyzioğlu, “The Life And Achievements Of Mustafa Kemal Atatürk”, Atatürk’s Way, İstanbul, 1982, s.329.

${ }^{50}$ Atay, Çankaya, s.18-19; Güler, "Mustafa Kemal'i Atatürk Yapan Süreçte Aile Çevresi...”, s.85.

${ }^{51}$ Atatürk'ün biyografisinde görülen tarih farklılığın sebeplerinden biri, belki de en önemlisi, hicrî ve rumî tarihleri, milâdî tarihe çevirirken yapılan hatalardır.

52 İğdemir, Atatürk'ün Yaşamı 1881-1918, s.4.
} 
ederdi. Ne kadar nazik, ne kadar sıkılgan bir çocuktu, size tarif edemem. Konu komşu her kes O'nu çok severdi. Çok zeki bir çocuktu. "53

Evet $\mathrm{O}$ bir çocuktu, annesinin tabiriyle zeki bir çocuktu. Fakat önceki mutluluğu bozulmuştu, babasını kaybetmişti, yani yetim büyüyordu. Ülkenin durumu da pek farklı değildi. Büyük bir hızla çöküşe doğru gidiyordu. O, Selanik'te dayısının kâhyalık yaptığı çiftlikte tarlalarda toprakla haşır neşir oldu ve çocukluk yıllarının zorluklarıyla vatan idealini perçinledi ve kendini askerî eğitiminin ilk aşaması olan Selanik Askeri Rüştiyesi'nde buldu. ${ }^{54}$

\section{Zübeyde Hanım, “Tanrının bana bu oğlu vatanı kurtarmak için gönderdiğ̈ine inanıyorum” diyordu. ${ }^{55}$}

Öyle de oldu, askeri eğitimini tamamlayan Atatürk zorluklarla dolu bir yola girdi. Zorlu bir mücadele ve başarılı bir liderlik süreci sonunda yeni bir devlet kurdu. Böylesine üstün vasıflı ve liderlik yeteneğine sahip insanların yetişmesinde yaşadığı çevre ve çocukluk yılları önemli rol oynamaktadır. Ayrıca çocukluk dönemlerinde yaşanan olayların liderlerin kişiliği üzerinde etkili olduğu da bilinmektedir. ${ }^{56} \mathrm{Bu}$ nedenle Atatürk'ün doğumu ve çocukluk yılları tabii ki büyük önem arz etmektedir.

$\mathrm{Bu}$ vesileyle Devletimizin Kurucusu Atatürk'ü doğumunun 125. y1lında milletçe bir kere daha minnet ve şükranla anıyoruz. Çünkü, Türk Milleti, O'nun önderliğinde vatanına sahip çıktı. Üzerine oynanan oyunları, hayalleri O'nunla beraber bozdu. Önündeki engelleri O’nunla aştı. Ümitsizliği O’nunla yendi, öz benliğine kavuştu. Dünya milletleri arasında saygın yerini aldı ve çağdaş medeniyet seviyesine ulaştı. O'ndan aldığı ilham ve güçle geleceğe güvenle bakmaya başladı. İşte bu yüzdendir ki Atatürk'ün doğumu, Türk Milleti için, Türk tarihi için bir dönüm noktası oldu.

\footnotetext{
${ }^{53}$ Kılıç Ali, Atatürk'ün Hususiyetleri, s.25-26.

${ }^{54}$ Sami Ateş, Atatürk Anadolu'ya Geçince, Ankara, Ocak 1991, 2.Bask1, s.70-71.

55 Türk Tarihi Silahlı Kuvvetleri ve Atatürkçülük, Genel Kurmay Başkanlığı 50 nci Yıl Yayını, s.220; Tahsin Aygün, Fotoğraflarla Atatürk, Ankara, 1963, s.7.

${ }^{56}$ Güler, "Mustafa Kemal'i Atatürk Yapan Süreçte Aile Çevresi...", s.80.
} 


\section{KAYNAKLAR}

AFETínAN, Ayşe; Mustafa Kemal Atatürk'ün Karlsbad Hatıraları,Yeni Gün Haber Ajansı Basın ve Yayıncılık A.Ş., Nisan 1999.

ANDREW MANGO, Atatürk, ( çev: Füsun Doruker ), İstanbul, 2000.

Atatürk 1880-1938, Ankara, 1939, Ulus Basımevi.

Atatürk Diyor ki Atatürk’ün Direktifleri Düşünceleri ve Kısaca Hayatı, İstanbul, 1966, Altınc1 Bask1, Varlık Yayınevi.

ATAY, Falih Rıfkı; Babanız Atatürk, Bayrak, Atatürkçülük Nedir, Atatürk Ne İdi, İstanbul, 1980.

ATAY, Falih Rıfkı; Çankaya, İstanbul, 1969.

ATEŞ, Sami; Atatürk Anadolu’ya Geçince, Ankara, Ocak 1991, 2.Bask1.

AYDEMIR, Şevket Süreyya; Tek Adam Mustafa Kemal (1881-1919), Üçüncü Bask1, İstanbul, 1966.

AYGÜN, Tahsin; Fotoğraflarla Atatürk, Ankara, 1963.

BANOĞLU, Niyazi Ahmet; Yayınlanmamış Belgelerle Atatürk Siyasi ve Özel Hayatı İlkeleri, İstanbul, 1981.

BAYUR, Hikmet; Atatürk Hayatı ve Eseri, Ankara, 1990.

BESLEYİİ, Hadi; Atamız Atatürk, Dilek Yayınevi, 1980.

BENOIST MECHIN, Mustafa Kemal Bir İmparatorluğun Ölümü, (çev: Zeki Çelikkol ), Ankara, 1997.

BİRCAN, Osman; Belge ve Fotoğraflarla Atatürk'ün Hayat1, İstanbul, 1993.

CEBESOY, Ali Fuat; Sınıf Arkadaşım Atatürk, İstanbul, 1967.

DEVELLİOĞLU, Ferit; Osmanlıca-Türkçe Ansiklopedik Lûgat, (Yayına Hazırlayan: Aydın Sami Güneyçal), Ankara, 1993.

ERGIIN, Feridun; Kemal Atatürk, Yaşar Eğitim ve Kültür Vakfı Yayınları, 1978.

ERİKAN, Celâl; Komutan Atatürk, Ankara, 1972.

EROĞLU, Hamza; Atatürk'ün Hayat1, Ankara, 1986. 
FEYZİOĞLU, Turhan; "The Life And Achievements Of Mustafa Kemal Atatürk", Atatürk’s Way, İstanbul, 1982.

GÖKSEL, Burhan; Atatürk'ün Soykütüğü Üzerine Bir Çalışma, Ankara, 1994.

GÖKTÜRK, Halil İbrahim; Atatürk ve Çağlarını Aşanlar, Sena Matbaası, 1981.

GÜLER, Ali; "Mustafa Kemal'i Atatürk Yapan Süreçte Aile Çevresi İle İlk Ve Orta Öğrenim Yaşantısının Rolü”, Atatürk ve Manastır Sempozyumu 12-13 Ekim 1998, Ankara, 1999.

GÜLER, Ali; Atatürk Soyu Ailesi ve Öğrenim Hayatı, Ankara, 1999.

GÜNEY, Eflâtun Cem; Atatürk Hayatı ve Eserleri, İstanbul, 1963.

GÜNGÖR, Selâhaddin; Öz Dilimizle Atatürk, Maarif Matbaası, 1935.

Her Yönüyle Atatürk, (Editör: Avni Altıner), İstanbul, 1974, 2.Bask1.

İĞDEMİR, Uluğ; Atatürk'ün Yaşamı 1881-1918, I. Cilt, Ankara, 1988.

İslâm Ansiklopedisi, Eskişehir, 1997, C.I.

JORGE BLANCO VÍLLALTA, Atatürk, Ankara, 1979.

KARTAL, Numan; Atatürk ve Kocacık Türkleri, Ankara, 2002.

KILIÇ ALİ, Atatürk'ün Hususiyetleri, Yeni Gün Haber Ajansı Basın ve Yayıncılık A.Ş., 1998.

KOCATÜRK, Utkan; Atatürk, Ankara, 1987.

KUMRAL, A. Muhtar; Atatürk Diktatör müdür ?, İstanbul, 1949.

KUTAY, Cemal; Atatürk Olmasaydı?, İstanbul, 1993.

LORD KİNROSS, Atatürk Bir Milletin Yeniden Doğuşu, (çev: Ayhan Tezel), İstanbul, 1978.

LORD KINROSS, Atatürk The Rebirth Of A Nation, , London, , 1966.

OMURTAK, Salih vd.; Atatürk, İstanbul, 1970.

ÖZEL, Mehmet; Atatürk, T.C. Kültür Bakanlığı Güzel Sanatlar Genel Müdürlüğü, (albüm).

PERRONE DI SAN MARTINO, Ön Asya Diktatörü Mustafa Kemal ve Zaferleri, İstanbul, 1998. 
SERTOĞLU, Midhat; Osmanlı Tarih Lûgatı, İstanbul, 1986.

SÖNMEZ, Cemil; Atatürk ve Çocuklar, UNICEF Türkiye Temsilciliği, 1991.

ŞAPOLYO, Enver Behnan; Kemal Atatürk ve Milli Mücadele Tarihi, Ankara, 1944.

ŞEHSUVAROĞLU, Halûk; Tarihçi Gözüyle Atatürk, Ankara, 1963.

ŞEKERCIOĞLU, Hüseyin; “Atatürk'ün Soy ve Sülalesi Hakkında Anadolu'da Yaptı̆̆ım Araştırmalar", Türk Kültürüu, Kasım 1974, S.145.

THOMAS A VAİDís, Kemal Atatürk Yeni Türkiye'nin Kurucusu -Yunanlı gözüyle Atatürk-, (çev; Ahmet Angın), İstanbul, 1967.

TÜNAY, Bekir, Gazi'nin Doğuş Destanı I, Ankara, 1981.

Türk Tarihi Silahlı Kuvvetleri ve Atatürkçülük, Genel Kurmay Başkanlığı 50 nci Yıl Yayını.

UCA, Alaattin; "Türk Toplumunda Ad Verme Geleneği”, Türkiyat Araştırmaları Enstitüsü Dergisi, Erzurum, 2004, S.23. 